Article

\title{
Benefits of Precision Farming Technologies for Mechanical Weed Control in Soybean and Sugar Beet-Comparison of Precision Hoeing with Conventional Mechanical Weed Control
}

\author{
Christoph Kunz, Jonas Felix Weber and Roland Gerhards *
}

Department of Weed Science, Institute of Phytomedicine, University of Hohenheim, 70599 Stuttgart, Germany; E-Mails: Christoph.Kunz@uni-hohenheim.de (C.K.); j.weber@uni-hohenheim.de (J.F.W.)

* Author to whom correspondence should be addressed;

E-Mail: Roland.Gerhards@uni-hohenheim.de; Tel.: +49-711-45922399; Fax: +49-711-45922408.

Academic Editor: Rakesh S. Chandran

Received: 13 March 2015 / Accepted: 17 April 2015 / Published: 23 April 2015

\begin{abstract}
Weed infestations and associated yield losses require effective weed control measures in soybean and sugar beet. Besides chemical weed control, mechanical weeding plays an important role in integrated weed management systems. Field experiments were conducted at three locations for soybean in 2013 and 2014 and at four locations for sugar beet in 2014 to investigate if automatic steering technologies for inter-row weed hoeing using a camera or RTK-GNSS increase weed control efficacy, efficiency and crop yield. Treatments using precision farming technologies were compared with conventional weed control strategies. Weed densities in the experiments ranged from 15 to 154 plants $\mathrm{m}^{-2}$ with Chenopodium album, Polygonum convolvulus, Polygonum aviculare, Matricaria chamomilla and Lamium purpureum being the most abundant species. Weed hoeing using automatic steering technologies reduced weed densities in soybean by $89 \%$ and in sugar beet by $87 \%$ compared to $85 \%$ weed control efficacy in soybean and sugar beet with conventional weeding systems. Speed of weed hoeing could be increased from $4 \mathrm{~km} \mathrm{~h}^{-1}$ with conventional hoes to 7 and $10 \mathrm{~km} \cdot \mathrm{h}^{-1}$, when automatic steering systems were used. Precision hoeing technologies increased soybean yield by $23 \%$ and sugar beet yield by $37 \%$. After conventional hoeing and harrowing, soybean yields were increased by $28 \%$ and sugar beet yield by $26 \%$.
\end{abstract}


Keywords: mechanical weed control; automatic steering systems; sensor technologies; integrated weed management

\section{Introduction}

Soybean and sugar beet are both very sensitive to weed competition with yield losses of 15\%-40\% in soybean [1] and 77\% in sugar beet [2] recorded even at low weed densities of 5 plants $\mathrm{m}^{-2}$. In addition to yield losses, weeds in soybean and sugar beet reduced crop quality, complicated harvest and served as hosts for insect pests and diseases pathogens [3]. Strong weed competition in soybean and sugar beet can be explained by favorable growing conditions for weeds in spring at the time of sowing, relatively slow crop growth in the early vegetation period and wide row spacing [1]. In Germany, Chenopodium album L., Galium aparine L., Matricaria chamomilla L. and M. inodora L., Stellaria media (L.) Vill. and Polygonum convolvulus L. [4,5] are most frequent in sugar beet; Echinochloa crus-galli L., Chenopodium album L., Amaranthus retroflexus L. and Solanum nigrum L. are the main weeds listed in soybean [6].

Under European cropping conditions, weed control in soybean and sugar beet is mostly performed by combinations of pre-emergent and post-emergent herbicide applications [4,7,8]. Yet, herbicide treatments can decrease the quality of the crop. In particular, the studies of Wilson [9] showed that different post-emergence herbicides reduced sugar beet leaf area up to $29 \%$ in case of two triflusulfuron applications. The use of ethofumesate plus desmedipham plus phenmedipham resulted in a $22 \%$ reduction in leaf area. He pointed out that sugar beet cultivars differed with regard to the response towards herbicides. Root yield reduction of nine investigated sugar beet cultivars provoked by herbicide treatments ranged from 3 to $11 \%$.

Furthermore, it could be shown that certain herbicides remain in soil and water [10]. Repeated use of herbicides with the same mode of action resulted in the evolution of herbicide resistant weed populations [11]. For example, resistant populations of Chenopodium album L. to metamitron in sugar beet [12] and Apera spica-venti L. Beauv. to branched chain amino acid synthesis inhibitors in winter wheat [13]. Integration of preventive, non-chemical and chemical methods of weed control with reduced doses have successfully been carried out in several studies in soybean and sugar beet [1,14-17]. Gummert et al. [18] summarized integrated weed management strategies for sugar beet production.

A promising alternative to chemical weed control is weed hoeing, which can be done between the row (inter-row hoeing) and within crop rows (intra-row hoeing). For soybean in Europe, in-row hoeing occupied around $20 \%$ and intra-row hoeing less than $1 \%$. Intra- and inter-row hoeing in sugar beet did not exceed $1 \%$. Hoeing can control larger weeds and grass-weeds, which are difficult to remove by flexible tine harrows and the risk of crop damage for inter-row hoeing, is usually lower compared to harrowing [19,20]. Dierauer and Stöppler-Zimmer [21] found that $90 \%$ of the weeds between the crop rows were uprooted and $75 \%$ of the weeds within the crop row were covered by soil after two passes of hoeing in maize and peas. However, the effect strongly depends on soil conditions, weed species and growth stages of weed species. Highest efficacies were achieved when crops at the time of hoeing were taller than the weeds [21-23]. 
The use of mulch systems can reduce soil erosion and surface runoff of soil particles by more than $50 \%$ [24]. Gummert et al. [18] mentioned that the erosion risk was enhanced after hoeing, due to incorporation of organic matter into the soil. However, weed hoeing in arable crops reduced water evaporation from the soil surface, which is of concern in areas with low rainfall in early summer [22]. Few studies were conducted to investigate weed control efficacy, crop response and yield effect of weed hoeing in sugar beet and soybean.

New automatic row guidance systems for inter-row hoeing have been developed in the last 15 years [25-28]. Optical sensors and RTK-GNSS technologies identify the position of crop rows and hydraulic systems steer inter-row hoes close to crop rows. However, little information is available on the performance of these technologies in sugar beet and soybean.

The objectives of this study were to investigate innovative weed control methods using precision farming technologies for mechanical weed management in soybean and sugar beet in comparison with conventional hoeing methods. Optical sensors and high accuracy RTK-GNSS were applied to guide mechanical hoes close to the crop row. We investigated if those precision farming technologies were capable of increasing weed control efficacy and crop yield. We also tested if precision farming technologies allowed hoeing at higher speeds compared to conventional hoeing. We hypothesized precision hoeing technologies had significant weed suppressive effects within crop rows due to soil coverage especially at higher driving speeds.

\section{Results and Discussion}

\subsection{Weed Density}

Weed densities in the untreated plots varied from 15 to 150 plants $\mathrm{m}^{-2}$ with the highest weed density in soybean at March-Buchheim in 2013 and the lowest density in sugar beet at Renningen in 2014. The most abundant weed species observed were common lambsquarters (Chenopodium album), wild buckwheat (Polygonum convolvulus), prostrate knotweed, (Polygonum aviculare L.), wild chamomile (Matricaria chamomilla), and purple deadnettle (Lamium purpureum L.). Weed species composition was typical for German soybean and sugar beet production areas [5,6].

All treatments significantly reduced weed density compared to the untreated control. When averaged over all treatments, weed hoeing using automatic steering technologies reduced weed densities in soybean by $89 \%$ and in sugar beet by $87 \%$ compared to $85 \%$ weed control efficacy in soybean and sugar beet with conventional weeding systems (Figure 1). Highest weed control efficacy in sugar beet was achieved with a goosefoot hoe steered by RTK-GNSS reducing weed density to 5 plants $\mathrm{m}^{-2}$ compared to 52 plants $\mathrm{m}^{-2}$ in the control treatment. Weed control efficacy in the inter-row area was not significantly different from efficacy within crop rows (data not shown). This was possibly due to the fact that hoeing blades uprooted weeds between crop rows and covered weeds with soil within rows with both effects leading to high control efficacy. Weed control efficacy in soybean using precision hoeing systems was slightly higher at a speed of 7 and $10 \mathrm{~km} \mathrm{~h}^{-1}$ compared to $4 \mathrm{~km} \mathrm{~h}^{-1}$.

In conventional soybean treatments, combinations of hoeing and harrowing reduced weed density from 154 to 19 plants $\mathrm{m}^{-2}$. Only hand weeding completely eliminated all weeds (Figure 1). The conventional weed control treatments in sugar beet using herbicides and combinations of flexible 
tine harrowing with herbicide resulted in highest reduction of weed density from 15 to 1.5 plants $\mathrm{m}^{-2}$ (Figure 1). The use of a finger-weeder within crop rows did not significantly increase weed control efficacy compared to hoeing without a finger weeder. The type of hoeing blades (cutting blade and goosefoot-blades) did not have significant effects on weed control efficacy.
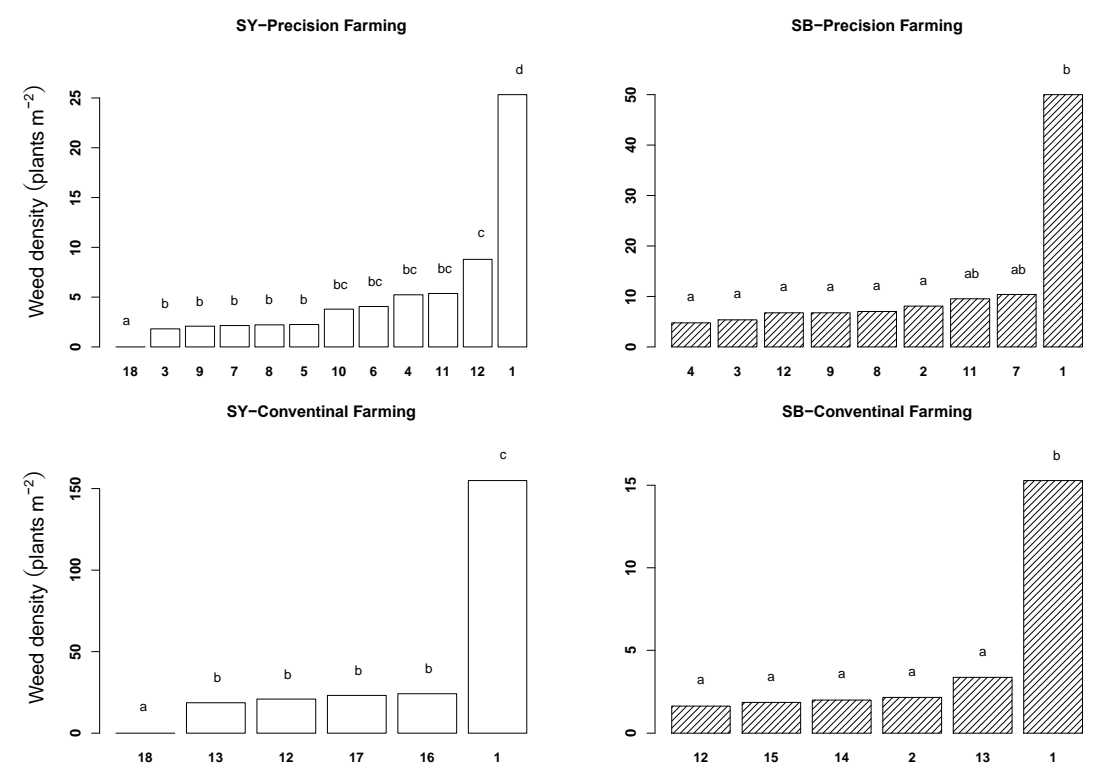

Figure 1. Weed density in sugar beet (SB) and soybean (SY) measured directly after last weed hoeing using automatic steering technologies and conventional weed control methods; soybean experiments were conducted at Kleinhohenheim and March-Buchheim in 2013 and Kleinhohenheim and Ihinger Hof in 2014; sugar beet experiments were carried out at Gützingen, Ihinger Hof, Heidfeldhof and Renningen in 2014. Precision farming technologies were tested in SB and SY in 2014. Data of the conventional weed control of different locations were averaged. Mean values within the same column followed by an identical letter do not differ statistically based on the Tukey HSD test $(p \leq 0.05)$.

Weed control efficacies were slightly higher than in the studies by Dierauer and Stöppler-Zimmer [21], and almost equal to chemical weed control strategies. Melander et al. [29] suggested that hoeing at higher speed could increase soil coverage of intra-row weeds and thus may lead to higher weed suppression. We could prove this hypothesis in our study. Hoeing in soybean resulted in higher weed control efficacy at a speed of 7 and $10 \mathrm{~km} \mathrm{~h}^{-1}$ compared to $4 \mathrm{~km} \mathrm{~h}^{-1}$ without causing crop damage, when automatic steering systems were applied. Camera steering systems or high accuracy RTK-GNSS-technologies allowed weed hoeing at almost double speed. Higher driving speeds and autonomous operations reduce labor costs for mechanical weeding. Reduced labor costs may compensate for the investment in precision steering technologies. We assume that automatic steering technologies in general make mechanical weed control methods more attractive for practical farming and in future those machines could be operated completely autonomous [27]. In the given study, the use of camera steering and RTK-GNSS hoeing techniques caused similar margin contributions to the chemical weed control. Nevertheless, the application of mechanical weed control is highly cost intensive, time consuming and less area efficient. Furthermore, additional conditions for application (e.g., temperature, soil moisture, soil texture) have to be satisfied in comparison to chemical approaches. The strong dependency on weather conditions for 
mechanical weed control has already been shown in Kurstjens and Kropff [30]. Therefore, if mechanical weed control is not applicable or successful, an additional cost-effective chemical measure is necessary.

At present chemical weed control is still a prerequisite for economic and sustainable crop production in Europe. The high amount of herbicides on total pesticide use indicates the importance of weed control for economic crop production [18].

\subsection{Crop and Weed Biomass}

Soybean dry shoot biomass six weeks after treatment was significantly lower in the untreated control plots compared to all treatments. The lowest crop biomass was observed in the control treatment at IHO (3111 kg ha ${ }^{-1}$ ). Highest crop biomass of $6363 \mathrm{~kg} \mathrm{ha}^{-1}$ was measured after RTK-hoeing with finger weeders. Weed biomass was lowest (in average $0.19 \mathrm{~kg} \mathrm{ha}^{-1}$ ) in the RTK-hoeing treatments with and without finger-weeder compared to $2700 \mathrm{~kg} \mathrm{ha}^{-1}$ in the control plots. After conventional weed control, average soybean biomass was $4698 \mathrm{~kg} \mathrm{ha}^{-1}$ compared to $3282 \mathrm{~kg} \mathrm{ha}^{-1}$ in the control treatment. The lowest weed biomass of $0 \mathrm{~kg} \mathrm{ha}^{-1}$ was measured after hand-weeding followed by harrowing and hoeing with $184 \mathrm{~kg} \mathrm{ha}^{-1}$ (Figure 2).
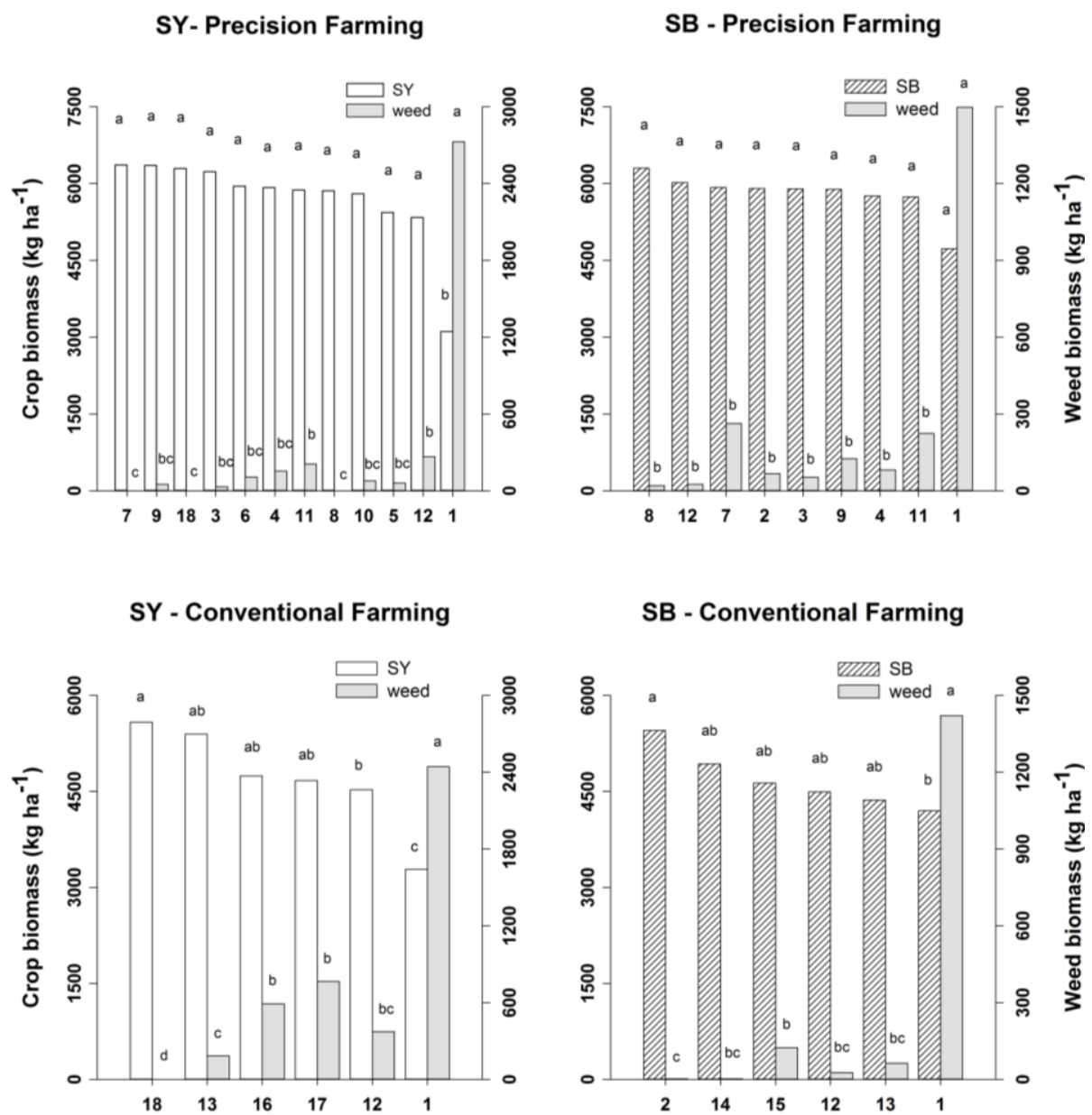

Figure 2. Shoot dry biomass of weeds and soybean (SY), shoot and root dry biomass of sugar beet (SB) measured eight weeks after sowing; weeds were controlled using automatic steering technologies and conventional weed control methods; soybean experiments were conducted at Kleinhohenheim and March-Buchheim in 2013 and Kleinhohenheim and 
Ihinger Hof in 2014; sugar beet experiments were carried out at Gützingen, Ihinger Hof, Heidfeldhof and Renningen in 2014. Precision farming technologies were tested in SB and SY in 2014. Data of the conventional weed control of different locations were averaged. Mean values within the same column followed by an identical letter do not differ statistically based on the Tukey HSD test $(p \leq 0.05)$.

In sugar beet, all treatments significantly increased dry crop shoot and root biomass. Precision hoeing treatments did not significantly differ from each other (Figure 2). Crop biomass was lowest in the control plots with $4035 \mathrm{~kg} \mathrm{ha}^{-1}$ and highest (6302 $\mathrm{kg} \mathrm{ha}^{-1}$ ) after shallow RTK-hoeing with finger-weeder. Weed biomass in average was reduced to $127.5 \mathrm{~kg} \mathrm{ha}^{-1}$ after precision hoeing in sugar beet. The deep RTK-hoeing with the finger-weeder resulted in the lowest weed biomass. Conventional weed control methods also significantly increased sugar beet biomass and decreased weed biomass compared to the control plot. Sugar beet dry biomass was highest after the herbicide application with $5451 \mathrm{~kg} \mathrm{ha}^{-1}$. The lowest crop biomass of $4197 \mathrm{~kg} \mathrm{ha}^{-1}$ was observed in the control plots. Weed biomass was highest in the control plots with $1420 \mathrm{~kg} \mathrm{ha}^{-1}$. The treatments hoeing, harrowing plus hoeing, harrowing plus herbicide and hoeing with cutting blade reduced weed biomass in average by $95 \%$. The correlation between mean crop yield and mean weed biomass was found to be negative. Sugar beet and soybean yields expressed correlation coefficient values of $r=-0.32$ and -0.72 , respectively, to weed biomass.

The results of Figure 2 support very high weed control efficacies presented in Figure 1 and suggest that early weed competition causes significant dry crop biomass and yield losses in soybean and sugar beet. All mechanical weed control methods did not reduce crop biomass compared to hand-weeding and herbicide applications. Therefore, we can conclude, that weed hoeing in soybean and sugar beet was very selective.

\subsection{Crop Yield}

Yields of soybean and sugar beet were significantly higher in all treatments compared to the control plots demonstrating the importance of effective weed control in both crops.

In the precision hoeing experiment, the highest soybean yield of $3.2 \mathrm{t} \mathrm{ha}^{-1}$ was recorded in the hand-weeding plots, where weed competition was completely eliminated (Figure 3). Lowest yield was measured in the control plots with $2.5 \mathrm{t} \mathrm{ha}^{-1}$. Precision hoeing using a camera guidance system or RTK-GNSS system at the speeds of 7 and $10 \mathrm{~km} \mathrm{~h}^{-1}$ resulted in a yield of $3.1 \mathrm{t} \mathrm{ha}^{-1}$ compared to the same treatment at the lower speed $\left(4 \mathrm{~km} \mathrm{~h}^{-1}\right)$ yielding $3 \mathrm{t} \mathrm{ha}^{-1}$ (not significant). After conventional weed control, highest soybean yield of $2.5 \mathrm{t} \mathrm{ha}^{-1}$ was again recorded in the hand-weeded treatment. Conventional hoeing, harrowing and hoeing and harrowing and hoeing in turn yielded at $2.3 \mathrm{t} \mathrm{ha}^{-1}$, $2.4 \mathrm{t} \mathrm{ha}^{-1}$ and $2.2 \mathrm{t} \mathrm{ha}^{-1}$, respectively. Harrowing alone showed $12.5 \%$ less yield than the combination of hoeing and harrowing. Without any weed control, soybean yield was only $1.8 \mathrm{t} \mathrm{ha}^{-1}$.

White sugar yields ranged from $10.1 \mathrm{t} \mathrm{ha}^{-1}$ in the control plots to $14.6 \mathrm{t} \mathrm{ha}^{-1}$ after RTK-hoeing (Figure 3). Yields were equal among all precision hoeing treatments with an average of $13.5 \mathrm{t} \mathrm{ha}^{-1}$.

In sugar beet, averaged over all conventional treatments at all locations highest white sugar yield was observed in the herbicide treatment with $15.8 \mathrm{t} \mathrm{ha}^{-1}$. The combination of harrowing and hoeing and harrowing with herbicide resulted in significantly higher yields than the hoeing treatments with 
goosefoot-blades and cutting-blade (Figure 3) indicating that harrowing in sugar beet might favor crop growth. Treatments had no statistical effect on sugar content (data not presented).
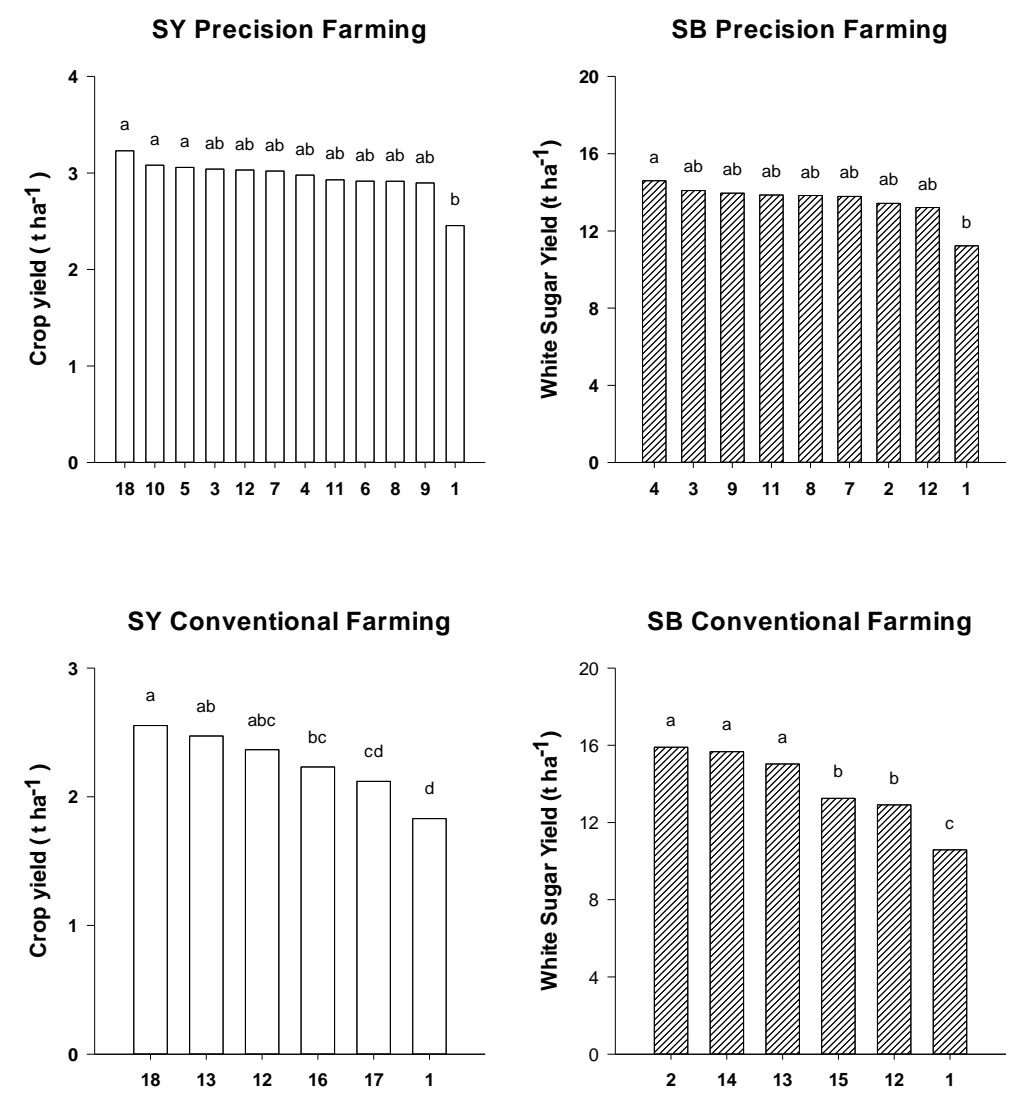

Figure 3. Yield of crop in $\mathrm{tha}^{-1}$ in the sugar beet (SB) and soybean (SY) treatment at Ihinger Hof, Gützingen, Heidfeldhof, Renningen, Kleinhohenheim in the year 2013 and 2014 and March-Buchheim in 2013. Precision farming experiments were conducted at Ihinger Hof in SB and SY in 2014. Data of the conventional farming experiments of different locations were averaged. Bars represent mean values, within each experiment and measurement date, significant differences $(p \leq 0.05)$ are topped by different letters.

\section{Experimental Section}

\subsection{Experimental Sites and Design}

Soybean trials in 2013 were located at Kleinhohenheim $(\mathrm{KH}),\left(48.73^{\circ} \mathrm{N}, 9.20^{\circ} \mathrm{E}, 400 \mathrm{~m}\right.$ altitude) and March-Buchheim (MB) $\left(48.06^{\circ} \mathrm{N}, 7.78^{\circ} \mathrm{E}, 219 \mathrm{~m}\right.$ altitude). In 2014, soybean experiments were carried out at $\mathrm{KH}$ and the experimental station of the University of Hohenheim Ihinger Hof (IHO) ( $48.74^{\circ} \mathrm{N}, 8.92^{\circ} \mathrm{E}, 478 \mathrm{~m}$ altitude). Sugar beet experiments in 2014 were conducted at Gützingen (GÜ) $\left(49.62^{\circ} \mathrm{N}, 9.88^{\circ} \mathrm{E}, 290 \mathrm{~m}\right.$ altitude), IHO, Heidfeldhof (HD) $\left(48.71^{\circ} \mathrm{N}, 9.19^{\circ} \mathrm{E}, 370 \mathrm{~m}\right.$ altitude) and Renningen $(\mathrm{RE}),\left(48.74^{\circ} \mathrm{N}, 8.90^{\circ} \mathrm{E}, 478 \mathrm{~m}\right.$ altitude). All experimental fields were located in the southwest of Germany. At IHO the soil was a deep loam on subsoil clay. The soil in RE was a sandy to silty loam. In KH, GÜ and HD, soils were characterized as silty loam. Average yearly rainfall varied between $660 \mathrm{~mm}$ in $\mathrm{KH}$ and $790 \mathrm{~mm}$ in IHO and average temperatures ranged from $9.2{ }^{\circ} \mathrm{C}$ in IHO to $10.2{ }^{\circ} \mathrm{C}$ in MB. All experiments were designed as a randomized complete block design with four 
replicates. The plot size was $20-30 \mathrm{~m}^{-2}$ depending on the machinery used for sowing. Row distance was $0.5 \mathrm{~m}$ in both crops.

\subsection{Set up of Experiments}

Soybean, $c v$. Sultana was sown on 4 June and 16 June in 2013 and 6 May and 8 May in 2014 at a density of 60 seeds $\mathrm{m}^{-2}$ with an experimental drilling machine (Deppe). The seeds were inoculated with HiStick $^{\circledR}$ (Bradyrhizobium japonicum) directly before sowing. Fields were ploughed during winter and cultivated twice in April/May before sowing.

Sugar beet, $c v$. Hannibal was sown in March 2013 at a density of 100,000 seeds ha $^{-1}$ with a precision driller (Kuhn Maxima 2Tl) after seed-bed cultivation. Seeds were treated with $0.6 \mathrm{mg}$ a.i. seed $^{-1}$ thiamethoxam [3-[(2-chloro-5-thiazolyl)methyl]tetrahydro-5-methyl-N-nitro-4H-1,3,5-oxadiazin-4-imine] and $0.08 \mathrm{mg}$ a.i. seed ${ }^{-1}$ tefluthrin [(2,3,5,6-tetrafluoro-4-methylphenyl) methyl(1R,3R)-rel-3-[(1Z)-2chloro-3,3,3-trifluoro-1-propenyl]-2,2-dimethylcyclo-propanecarboxylate]. Winter cereals were grown in the previous year before the experiments were set up. After harvest of winter cereals, white mustard (Sinapis alba L.) was cultivated as a cover crop. Approximately 3 weeks before sowing of sugar beet, 4 $\mathrm{L} \mathrm{ha}^{-1}$ Taifun $^{\circledR}$ Forte (360 g a.i. $\mathrm{L}^{-1}$ glyphosate [N-(phosphonomethyl)glycine]) and nitrogen (120 kg $\left.\mathrm{ha}^{-1} \mathrm{~N}\right)$ as urea ammonium nitrate $(47 \% \mathrm{~N})$ were applied. Shortly after emergence of sugar beet, $4 \mathrm{~kg} \mathrm{ha}^{-1}$ Frunol Delicia ${ }^{\circledR}$ slug-lentils were spread (30 g a.i. $\mathrm{kg}^{-1}$ metaldehyde [2,4,6,8-tetramethyl1,3,5,7-tetraoxacyclooctane]).

Experiments included 18 treatments (Table 1). Six conventional mechanical weed control methods were applied pre-emergence harrowing with a flexible-tine harrow (Hatzenbichler, $3 \mathrm{~m}$ wide) and post-emergence hoeing with goose-foot blades or cutting blades alone, and the combination of hoeing and harrowing and a combination of harrowing with herbicides in sugar beet were tested at five locations (GÜ, HD, RE, KH, MB). In treatment 16, pre-emergence harrowing was followed by post-emergence hoeing, post-emergence harrowing and again post-emergence hoeing. Post-emergence harrowing and hoeing was carried out between 2 and 8 leaf stages of the crops.

Precision inter-row hoeing using automatic steering technology alone or in combination with the finger-weeders [23] in the intra-row area was investigated in nine treatments (treatment 3-11). These technology were only available at IHO in 2014. A Kult-robocrop ${ }^{\circledR}$ hoe with a width of $3 \mathrm{~m}$ was used for precision hoeing (Figure 4). The hoe was equipped with 6 goose-foot blades or cutting blades at a distance of $0.5 \mathrm{~m}$ for inter-row weeding and twelve finger-weeders running over the crop rows. Using a DGPS receiver with RTK correction signal during sowing, a virtual AB-line was created. According to this AB-line, the seed rows are oriented parallel. The hoe was guided along the virtual AB-line with a distance of $5 \mathrm{~cm}$ to the crop row using an automatic steering system on the tractor so that the hoeing blade is situated right between the crop rows. Alternatively to GNSS-steering, a camera was placed above the rows pointing forwards to determine the row position. Based on the position of crop rows, an active control of the hoe was performed. Camera and image analysis system were adjusted to row spacing. 
Table 1. Description of experimental treatments investigated in soybean (SY) 2013/2014 and sugar beet (SB) in 2014 .

\begin{tabular}{|c|c|c|c|c|}
\hline \multicolumn{2}{|c|}{ Crop } & \multirow{2}{*}{$\frac{\text { Treatment }}{1}$} & \multirow{2}{*}{$\frac{\text { Description }}{\text { No weed control }}$} & \multirow[t]{2}{*}{ Speed $(\mathbf{k m} / \mathbf{h})$} \\
\hline SB & SY & & & \\
\hline SB & & 2 & Herbicide & 5 \\
\hline & & & Precision hoeing & \\
\hline SB & SY & 3 & RTK hoe, $2 \mathrm{~cm}$ deep & 7 \\
\hline \multirow[t]{3}{*}{ SB } & SY & 4 & RTK hoe, $2 \mathrm{~cm}$ deep & 4 \\
\hline & SY & 5 & RTK hoe, $5 \mathrm{~cm}$ deep & 7 \\
\hline & SY & 6 & RTK hoe, $5 \mathrm{~cm}$ deep & 4 \\
\hline SB & SY & 7 & RTK hoe $2 \mathrm{~cm}$ deep with finger-weeder & 7 \\
\hline SB & SY & 8 & RTK hoe $2 \mathrm{~cm}$ deep with finger-weeder & 4 \\
\hline SB & SY & 9 & Camera hoe, $2 \mathrm{~cm}$ deep & 10 \\
\hline SB & SY & 10 & Camera hoe, $2 \mathrm{~cm}$ deep & 7 \\
\hline \multirow[t]{2}{*}{ SB } & SY & 11 & Camera hoe, $2 \mathrm{~cm}$ deep & 4 \\
\hline & & & Conventional hoeing & \\
\hline SB & SY & 12 & Conventional hoe, $2 \mathrm{~cm}$ deep & 4 \\
\hline SB & SY & 13 & Pre-emergence harrow and hoe, $2 \mathrm{~cm}$ deep & $7 / 4$ \\
\hline SB & & 14 & Pre-emergence harrow and herbicide & $7 / 5$ \\
\hline \multirow[t]{4}{*}{ SB } & & 15 & Hoe with cutting blade, $2 \mathrm{~cm}$ deep & 4 \\
\hline & SY & 16 & $\begin{array}{c}\text { Pre- }+ \text { post-emergence harrow }+ \text { hoe } 2 \mathrm{~cm} \\
\text { deep }\end{array}$ & $7 / 4$ \\
\hline & SY & 17 & Post-emergence harrow, 3 times & 7 \\
\hline & SY & 18 & Repeated hand weeding & \\
\hline
\end{tabular}

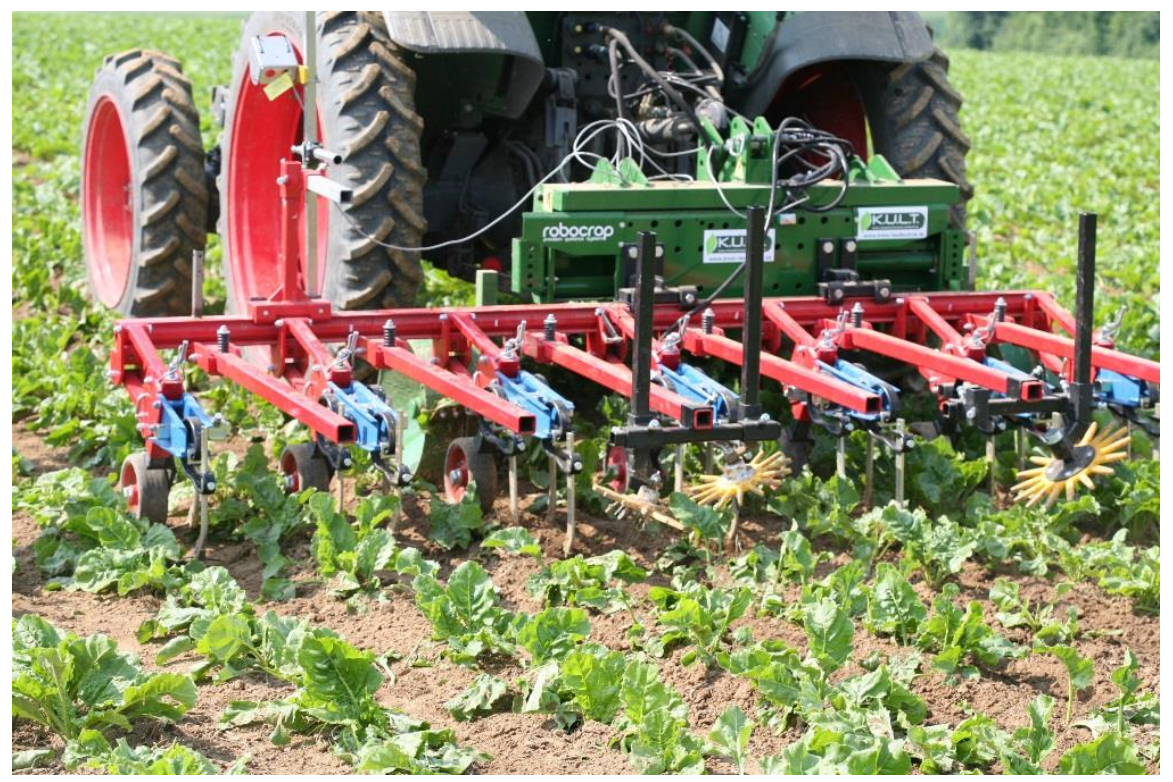

Figure 4. Photo of the Kult-robocrop ${ }^{\circledR}$ hoe with a camera-based automatic steering system in sugar beet at 8-leaf stage at Ihinger Hof.

An untreated control was included in all experiments (treatment 1). In soybean, repeated hand-weeding was carried out in one treatment to analyze soybean growth and yield without the effects of weed competition (treatment 18). In sugar beet, one treatment contained only chemical weed control 
with $200 \mathrm{~L}_{\text {water }} \mathrm{ha}^{-1}$ at each time of application (treatment 2). A mixture of $3 \mathrm{~L} \mathrm{ha}^{-1}$ Goltix Titan ${ }^{\circledR}$ (525 g a.i. $\mathrm{L}^{-1}$ metamitron [4-amino-3-methyl-6-phenyl-1,2,4-triazin-5(4H)-one] and $40 \mathrm{~g}$ a.i. $\mathrm{L}^{-1}$ quinmerac [7-chloro-3-methyl-8-quinolinecarboxylic acid]) and 4.5 $\mathrm{L} \mathrm{ha}^{-1}$ Betanal Expert $^{\circledR}\left(151 \mathrm{~g}\right.$ a.i. $\mathrm{L}^{-1}$ ethofumesate [2-ethoxy-2,3-dihydro-3,3-dimethyl-5-benzofuranyl methanesulfonate], $75 \mathrm{~g}$ a.i. $\mathrm{L}^{-1}$ phenmedipham [3-[(methoxycarbonyl)amino]phenyl (3-methylphenyl) carbamate], $25 \mathrm{~g}$ a.i. $\mathrm{L}^{-1}$ desmedipham [ethyl [3-[[(phenylamino)carbonyl]oxy]phenyl]carbamate]) was used three times, with equal rates at IHO, HD, RE and GÜ. Treatment dates are listed in Table 2. In treatment 14, pre-emergence harrowing was conducted and then herbicides were applied three times.

Table 2. Selection of treatments and timings for treatments (DAS = Days after sowing) in soybean (SY) and sugar beet (SB) experiments at locations Ihinger Hof (IHO), Gützingen (GÜ), Heidfeldhof (HD), Renningen (RE), Kleinhohenheim (KH) and March-Buchheim $(\mathrm{MB}) ;(\mathrm{PF}=$ Precision Farming; $\mathrm{CV}=$ Conventional Farming $)$.

\begin{tabular}{cccccc}
\hline Location & Cultivation Technology & Crop & Year & Treatment & DAS \\
\hline MB & CV & SY & 2013 & $12,13,16,17,18$ & $3,10,17,30$ \\
KH & CV & SY & 2013 & $12,13,16,17,18$ & $3,10,17,30$ \\
KH & CV & SY & 2014 & $12,13,16,17,18$ & $3,10,17,30$ \\
IHO & PF & SY & 2014 & $3,4-12$ & $27,37,50$ \\
MB & CV & SY & 2013 & $12,13,16,17,18$ & $3,10,17,30$ \\
IHO & PF & SB & 2014 & $2-4,7-12$ & $34,49,66$ \\
GÜ & CV & SB & 2014 & $2,13,14$ & $4,35,47,60$ \\
HD & CV & SB & 2014 & $2,12,15$ & $11,22,43$ \\
RE & CV & SB & 2014 & 2,13 & $3,27,45,59$ \\
& & & & & \\
\end{tabular}

\subsection{Data Collection}

Weed density was counted between the crop rows and in the intra-row area before the first treatment and directly after each treatment using a frame of $0.5 \mathrm{~m}^{-2}$ at three locations in each plot. Shoot and root biomass of sugar beet, soybean shoot biomass and weed biomass were measured eight weeks after sowing in an area of $1 \mathrm{~m}^{-2}$ in each plot. Plants were washed and dried at $80{ }^{\circ} \mathrm{C}$ for $48 \mathrm{~h}$. Then dry matter was determined. Soybean was harvested in October using a plot combine harvester (Hege 180). Sugar beet was harvested in September/October with a plot harvester (Edenhall 623). Yield was determined for dry soybean. Sugar beets were washed and then yield was measured. Sugar content was analyzed according to the standard procedure [31].

\subsection{Statistical Analysis}

Statistical analysis was conducted with statistical software language R version 3.1.1, "agricolae" package [32]. Data were fitted by a linear model (lm) using Equation (1):

$$
\mathrm{Y} i j k l=\mu+\alpha j+\beta i+\gamma k+\delta l+(\beta \gamma) i k+(\beta \delta) i l+(\gamma \delta) k l+(\beta \gamma \delta) i k l+e i j k l
$$

where Yijkl describes the yield in treatment $i$, block $j$, location $k$ and year $l, \alpha j$ is the effect of block $j, \beta i$ is the effect of treatment $i, \gamma k$ is the effect of location $k, \delta l$ is the effects of year $l,(\beta \gamma) i k$ represents the 
interaction of treatment $i$ and location $k,(\beta \delta) i l$ represents the interaction of treatment $i$ and year $l,(\gamma \delta) k l$ represents the interaction of location $k$ and year $l,(\beta \gamma \delta) i k l$ represents the interaction of treatment $i$, location $k$ and year $l$ and $e i j k l$ is the residual error in treatment $i$, block $j$, location $k$ and year $l$.

Weed density, weed and crop biomass, yield and sugar content were tested using analysis of variance. Afterwards, multiple comparison tests were performed using the Tukey HSD test at a significance level of $p \leq 0.05$. All data were analyzed using the Shapiro-Wilk test for normality and the Levene test for homogeneity of variance. If necessary, data were transformed to achieve the requirements for analysis of variance.

\section{Conclusions}

Automatic machine guidance systems for inter-row weed hoeing have slightly increased efficacy of weed control compared to conventional mechanical weed control methods.

However, further investigations and developments are needed to determine accuracy of precision steering systems and the optimal distance of hoeing blades to the crop rows. Inter-row hoeing could be combined with selective chemical (band-application) or mechanical weed control in the intra-row area. For intra-row hoeing, new sensor technologies differentiating between crops and weeds and automatic steering systems to guide the hoe exactly along and within a crop row [25,26,33,34] could be used. Weeds close to the crop, however, will remain a major constraint of mechanical weeding. Close-to-crop area needs to be defined for different crops and hoeing systems. This area needs to remain untreated to avoid crop damage.

\section{Acknowledgments}

The authors would like to thank Michael Baumann, Ralf Schill, Kathrin Jung, Florian Heerdes, Alexander Linn and Clarissa Frank for their help conducting field experiments and analyzing data. We thank Südzucker AG for providing technical support during sugar beet harvest and sugar analysis.

\section{Author Contributions}

Christoph Kunz designed the research of sugar beets, performed the analysis and wrote the paper. Jonas Felix Weber designed the research of soybeans and designed the graphs. Roland Gerhards conducted the final revision of the paper.

\section{Conflicts of Interest}

The authors declare no conflict of interest.

\section{References}

1. Hock, S.M.; Knezevic, S.Z.; Martin, A.R.; Lindquist, J.L. Soybean row spacing and weed emergence time influence weed competitiveness and competitive indices. Weed Sci. 2006, 54, $38-46$.

2. Kropff, M.J.; Spitters, C.J.T. A simple model of crop loss by weed competition from early observations on relative leaf area of the weeds. Weed Res. 1991, 31, 97-105. 
3. Bastiaans, L.; Kropff, M.J. WEEDS Weed Competition. In Encyclopedia of Applied Plant Sciences; Thomas, B., Ed.; Elsevier: Oxford, UK, 2003; pp. 1494-1500.

4. Petersen, J. A Review on Weed Control in Sugar beet: From Tolerance Zero to Period Threshold. In Weed Biology and Management, Inderjit; Kluwer Academic Publishers: Dordrecht, Netherlands, 2004; pp. 467-483.

5. Petersen, J.; Hurle, K. Einführung von herbizidresistenten Sorten: Konsequenzen für die Unkrautbekämpfung. Z. PflKankh. PflSchutz, Sonderh 1998, 16, 365-372.

6. Schroeder, D. A European weed survey in 10 major crop systems to identify targets for biological control. Weed Res. 1993, 33, 449-458.

7. Gehring, K.; Festner, T.; Gerhards, R.; Hüsgen, K.; Thyssen, S. Chemische Unkrautregulierung beim Anbau von Sojabohnen (Glycine Max, L.). Julius-Kühn-Archiv 2014, 443, 701-708.

8. Vasel, E.-H.; Ladewig, E.; Märländer, B. Weed composition and herbicide use strategies in sugar beet cultivation in Germany. J. Kult. 2012, 64, 112-125.

9. Wilson, R.G. Response of Nine Sugarbeet (Beta vulgaris) Cultivars to Postemergence Herbicide Applications. Weed Technol. 1999, 13, 25-29.

10. Bender, J. Change: Goals and Obstacles. In Future Harvest-Pesticide-Free Farming; Bender, J., Ed.; University of Nebraska Press: Lincoln, NE, USA, 1995; pp. 1-8.

11. Heap, I. The International Survey of Herbicide-Resistant Weeds. Available online: http://www.weedscience.org/summary/home.aspx (accessed on 22 September 2014).

12. Aper, J.; Mechant, E.; Rubin, B.; Heyerick, A.; Callebaut, G.; Mangelinckx, S. Absorp-tion, translocation and metabolism of metamitron in Chenopodium album. Pest Manag. Sci. 2012, 68, 209-216.

13. Massa, D.; Kaiser, Y.I.; Andújar-Sánchez, D.; Carmona-Alférez, R.; Mehrtens, J.; Gerhards, R. Development of a geo-referenced database for weed mapping and analysis of agronomic factors affecting herbicide resistance in Apera spica-venti L. Beauv. (Silky Windgrass). Agronomy 2013, $3,13-27$.

14. Buhler, D.D.; Gunsolus, J.L.; Ralston, D.F. Integrated Weed Management techniques to reduce herbicide inputs in soybean. Agron. J. 1992, 84, 973-978.

15. Hyvönen, T. Can conversion to organic farming restore the species composition of arable weed communities? Biol. Conserv. 2007, 137, 382-390.

16. Liebman, M.; Liedman, M.; Mohler, C.L.; Staver, C.P. Ecological Management of Agricultural Weeds; Cambridge University Press: Cambridge, UK, 2001.

17. Märländer, B.; Bräutigam, H. Influence of plant population on weed infestation as well as yield and quality of sugar beet-first step of integrated weed management. Gesunde Pflanzen 1994, 46, $117-121$.

18. Gummert, A.; Ladewig, E.; Märländer, B. Guidelines for integrated pest management in sugar beet cultivation-weed control. J. Kult. 2012, 64, 105-111.

19. Lötjönen, T.; Mikkola, H.J. Three mechanical weed control techniques in spring cereals. Agric. Food Sci. Finl. 2000, 9, 269-278. 
20. Rasmussen, J.; Ascard, J. Weed control in organic farming systems. In Ecology and Integrated Farming Systems: Proceedings of the 13th Long Ashton International Symposium on Arable Ecosystems for the 21 st Century; Glen, D.M., Greaves, M.P., Anderson, H.M., Eds.; John Wiley \& Sons: Chichester, UK, 1995; pp. 49-67.

21. Dierauer, H.U.; Stöppler-Zimmer, H. Unkrautregulierung ohne Chemie; Dierauer, H.U., Stöppler-Zimmer, H., Eds.; Eugen Ulmer Verlag: Stuttgart, Germany, 1994.

22. Bowman, G. Steel in the Field: A Farmer'S Guide to Weed Management Tools; Greg Bowmann: Beltsville, MD, USA, 1997.

23. Van der Weide, R.Y.; Bleeker, P.O.; Achten, V.T.J.M.; Lotz, L.A.P.; Fogelberg, F.; Melander, B. Innovation in mechanical weed control in crop rows. Weed Res. 2008, 48, 215-224.

24. Alliaume, F.; Rossing, W.A.H.; Tittonell, P.; Jorge, G.; Dogliotti, S. Reduced tillage and cover crops improve water capture and reduce erosion of fine textured soils in raised bed tomato systems. Agric. Ecosyst. Environ. 2014, 183, 127-137.

25. Nørremark, M.; Griepentrog, H.W.; Nielsen, J.; Søgaard, H.T. Evaluation of an autonomous GPS-based system for intra-row weed control by assessing the tilled area. Precis. Agric. 2012, 13, 149-162.

26. Ruckelshausen, A.; Klose, R.; Linz, A.; Marquering, J.; Thiel, M.; Tölke, S. Autonome Roboter zur Unkrautbekämpfung. Z. PflKankh. PflSchutz. Sonderh 2006, 10, 173-180.

27. Søgaard, H.T.; Olsen, H.J. Determination of crop rows by image analysis without segmentation. Comput. Electron. Agric. 2003, 38, 141-158.

28. Tillett, N.D.; Hague, T.; Miles, S.J. Inter-row vision guidance for mechanical weed control in sugar beet. Comput. Electron. Agric. 2002, 33, 163-177.

29. Melander, B.; Cirujeda, A.; Jørgensen, M.H. Effects of inter-row hoeing and fertilizer placement on weed growth and yield of winter wheat. Weed Res. 2003, 43, 428-438.

30. Kurstjens, D.A.G.; Kropff, M.J. The impact of uprooting and soil-covering on the effectiveness of weed harrowing. Weed Res. 2001, 41, 211-228.

31. Glattkowski, H.; Märländer, B. Umrechnung der Ergebnisse der Amino-N-Bestimmung in Zuckerrüben für die Verwendung in der Reinefeld-Formel nach Umstellung auf Aluminiumsulfat-Klärung und Fluorometrische Messung. Zuckerindustrie 1993, 118, 247-249.

32. R Core Team. A Language and Environment for Statistical Computing; R Foundation for Statistical Computing: Vienna, Austria, 2014.

33. Gerhards, R.; Oebel, H. Practical experiences with a system for site-specific weed control in arable crops using real-time image analysis and GPS-controlled patch spraying. Weed Res. 2006, 46, 185-193.

34. Wiltshire, J.J.J.; Tillett, N.D.; Hague, T. Agronomic evaluation of precise mechanical hoeing and chemical weed control in sugar beet. Weed Res. 2003, 43, 236-244.

(C) 2015 by the authors; licensee MDPI, Basel, Switzerland. This article is an open access article distributed under the terms and conditions of the Creative Commons Attribution license (http://creativecommons.org/licenses/by/4.0/). 